\title{
EDITORIAL: Thinking Through Ethnicities
}

In the spring of 1992 the Feminist Review collective decided to do a special issue for 1993 on 'Ethnicities' as part of our prioritizing of issues around gender, race and ethnicity (see the editorial in Feminist Review, Number 40, Spring 1992). The decision came out of our annual planning weekend at which we discuss the agenda for the following year and focus on what seem to us to be the pressing debates to which the journal could make a contribution. Within Europe it is clear that questions around ethnic identities have become vital and pressing. In other parts of the world (for example, Malaysia and parts of Africa) differences and antagonisms expressed around ethnicity had been part of the political, economic and social agenda for more than a decade. That the power of ethnicity as a key site of contestation would proliferate around the world to such an alarming extent was not something that we in Europe anticipated in the 1980 s.

In this context we were all aware that our approach to ideas about ethnicity would need to be fresh and complex, not least because historically the word 'ethnicity' has had problematic and politically oppressive connotations. For example, rarely has the term 'ethnic' in the mass of literature on the subject been used to refer to white identities or to imagined communities that have emerged in the West. Colonialism and imperialism have resulted in the ethnocentric idea that the white majority are not 'ethnic' - only Others are. Without any acknowledgement of the political implications of language, 'ethnic' has become a word in daily use on the BBC and in the press as news pours in of the eruptions associated with the break-up of the old socialist states. The reconstitution of old ethnic identities, the emergence of new ones and the violent struggles and conflicts associated with these developments have become part of our daily news. That most horrific term, 'ethnic cleansing' which we have grown so familiar with, is only the most graphic instance of the ways in which ethnic divisions have forced themselves into the popular imagination. To some extent this marks a shift in consciousness around issues of ethnicity in the 1990s. Yet that 
shift is only partial. Constant references to ethnic dress, ethnic jewellery, ethnic food, film and artifacts imply that the word 'ethnic' belongs only to those defined as Other.

At the political, at the popular and at the academic level, 'ethnicity' is a concept which we all need to come to terms with and 'ethnic identities' are identities which we need to be able to grasp and understand. This understanding is necessary if we are to come to terms with the contradictory nature of ethnicities and the ways in which ethnicism (the construction of culturally essentialized groups) becomes a tool to produce and reconstitute relationships of dominance and subordination. Conversely, such an understanding can also permit a view of the ways in which ethnic identities may help to constitute emancipatory strategies in which we move beyond essences into a recognition of difference as fluid and potentially empowering.

Our initial working title for the issue was 'Re-thinking Ethnicities'. As we worked on it we became aware that the idea of completely rethinking the subject was an impossibly ambitious aim. Since shifts in ethnic identities are taking place all the time and the ground is moving beneath our feet, the conceptual tools are poorly developed to rethink what ethnicity means. We hope that by highlighting certain moments and certain issues we will contribute to the debates that are going on and encourage further writing. There are case studies to be developed, the connexions between gender, sexuality and ethnicity to be elaborated, the articulation between ethnicity and class to be explored, the fantasy of 'imagined communities' to be assessed. What we hope to have achieved in this issue of the journal is to think through ethnicities - to look at issues through the lens of ethnicity, to contribute to the development of analytic clarity and to inform contemporary feminist politics.

Our focus in this issue is on Europe and the United States. We are well aware of the ethnicities we have not discussed, the issues we have neglected. Europe is a focus because of the dramatic developments since 1989 and the pressing problems which have emerged as old states have disappeared and new ones are struggling to achieve recognition. The emergence of 'Europe' as a world bloc and the dangers associated with the 'Fortress Europe' throw into relief questions of margin and centre. The mythical or presumed European cohesion suppresses those differences which are at its heart, whether these be in terms of the single market of the European Community or the geo-political region of Europe. Avtar Brah, Kum-Kum Bhavnani, Meg Coulson, Indijana Harper and Maja Korac, among others, address issues connected with this. In the United States ethnicity has been a term in common usage for a long time because of the historic place of immigration within that society. Here Ruth Frankenberg turns her attention to the constructions of a centralized ethnic identity, that of whiteness.

We realize that ethnic identities are being fought over in many parts of the world. Often such struggles have been focused through forms of religious belonging such as fundamentalism and we hope to 
return to this in later issues of Feminist Review. In the instances this special issue looks at, religion is not always a key dynamic in the construction of ethnic identities but the persecution of Bosnian Muslims and the effects this is already having on world politics provides a striking example of the dangers we face. We regret our lack of focus on the cultural aspects of ethnicity but are delighted to publish Ingrid Pollard's photo-essay and Jackie Kay's poem. These link us to the explosion of current work on black British ethnicities and identities in the field of cultural politics - again work which we hope will continue to be represented in Feminist Review. We do not yet know what are the theoretical grounds on which we might begin to construct new and more powerful ways of thinking through ethnicities. Such work must be a collective project and we hope that not only the articles and reports that we are publishing but also the access we are giving through them to books, articles and people will contribute to that long-term project.

At this critical moment ethnicity provides the ground on which issues about race and nation, about gender and nationalisms are being played out in Europe and elsewhere. What is meant by 'national sovereignty'? What defines a 'citizen'? Who is excluded and who is included? How are nations imagined? What part does gender play in the construction of nations? How are new subject positions and subjectivities being constituted in these processes? These are all questions which our contributors pose and which we see as crucial. The shedding and reconstitution of ethnic identities is an emotionally destabilizing and politically painful process. This is particularly the case when it occurs in the context of the violent recomposition of power relations. This pain is most eloquently expressed in the pieces by Indijana Harper and Maja Korac. The search for identity and meaning in their lives vividly encode this process. But these contributors also remind us that life goes on, that people, even when their lives are torn apart by the horrors of war, have the capacity to resist, to survive, to create and reconstruct. We need to provide support where we can. As a feminist journal our aim is also to find analyses which attempt to understand what is happening around us and to think through the implications of this for other places, other ethnicities...

Lorraine Gamman

Catherine Hall

Gail Lewis

Ann Phoenix

Annie Whitehead

Lola Young 